\title{
Complete genome sequence of Thermocrinis albus type strain $\left(\mathrm{HI} 11 / 12^{\mathrm{T}}\right)$
}

\author{
Reinhard Wirth ${ }^{1}$, Johannes Sikorski ${ }^{2}$, Evelyne Brambilla ${ }^{2}$, Monica Misra ${ }^{3,4}$, Alla Lapidus ${ }^{3}$, \\ Alex Copeland ${ }^{3}$, Matt Nolan ${ }^{3}$, Susan Lucas ${ }^{3}$, Feng Chen $^{3}$, Hope Tice ${ }^{3}$, Jan-Fang Cheng ${ }^{3}$, Cliff \\ Han $^{3,4}$, John C. Detter ${ }^{3,4}$, Roxane Tapia ${ }^{3,4}$, David Bruce ${ }^{3,4}$, Lynne Goodwin ${ }^{3,4}$, Sam Pitluck ${ }^{3}$, \\ Amrita Pati $^{3}$, Iain Anderson ${ }^{3}$, Natalia Ivanova ${ }^{3}$, Konstantinos Mavromatis ${ }^{3}$, Natalia \\ Mikhailova $^{3}$, Amy Chen ${ }^{5}$, Krishna Palaniappan ${ }^{5}$, Yvonne Bilek ${ }^{1}$, Thomas Hader ${ }^{1}$, Miriam \\ Land $^{3,6}$, Loren Hauser ${ }^{3,6}$, Yun-Juan Chang ${ }^{3,6}$, Cynthia D. Jeffries ${ }^{3,6}$, Brian J. Tindall ${ }^{2}$, Manfred \\ Rohde $^{7}$, Markus Göker ${ }^{2}$, James Bristow ${ }^{3}$, Jonathan A. Eisen ${ }^{3,8}$, Victor Markowitz ${ }^{5}$, Philip \\ Hugenholtz $^{3}$, Nikos C. Kyrpides ${ }^{3}$, and Hans-Peter Klenk ${ }^{2^{*}}$ \\ ${ }^{1}$ University of Regensburg, Archaeenzentrum, Regensburg, Germany \\ ${ }^{2}$ DSMZ - German Collection of Microorganisms and Cell Cultures GmbH, Braunschweig, \\ Germany \\ ${ }^{3}$ DOE Joint Genome Institute, Walnut Creek, California, USA \\ ${ }^{4}$ Los Alamos National Laboratory, Bioscience Division, Los Alamos, New Mexico, USA \\ ${ }^{5}$ Biological Data Management and Technology Center, Lawrence Berkeley National \\ Laboratory, Berkeley, California, USA \\ ${ }^{6}$ Oak Ridge National Laboratory, Oak Ridge, Tennessee, USA \\ ${ }^{7}$ HZI - Helmholtz Centre for Infection Research, Braunschweig, Germany \\ ${ }^{8}$ University of California Davis Genome Center, Davis, California, USA \\ *Corresponding author: Hans-Peter Klenk
}

Keywords: microaerophilic, (hyper-)thermophile, chemolithoautotrophic, biogeochemistry, non-sporeforming, Gram-negative, flagellated, non-pathogen, Aquificaceae, GEBA

Thermocrinis albus Eder and Huber 2002 is one of three species in the genus Thermocrinis in the family Aquificaceae. Members of this family have become of significant interest because of their involvement in global biogeochemical cycles in high-temperature ecosystems. This interest had already spurred several genome sequencing projects for members of the family. We here report the first completed genome sequence a member of the genus Thermocrinis and the first type strain genome from a member of the family Aquificaceae. The 1,500,577 bp long genome with its 1,603 protein-coding and 47 RNA genes is part of the Genomic Encyclopedia of Bacteria and Archaea project.

\section{Introduction}

Strain HI $11 / 12^{\mathrm{T}}$ (= DSM $14484=$ JCM 11386) is the type strain of the species Thermocrinis albus [1]. Officially, the genus Thermocrinis currently contains three species [2], however, it should be noted that at the time of writing, the $16 \mathrm{~S}$ rDNA sequence of the type strain of Thermocrinis ruber held in the DSMZ open collection as DSM 12173 does not correspond with that published under AJ005640. The generic name derives from the Greek word 'therme', meaning 'heat', and the Latin word 'crinis', hair, meaning 'hot hair', referring to the long hair-like filamentous cell structures found in the high-temperature environments, such as hot-spring outlets [3]. These long filaments are formed under conditions where there is a continuous flow of medium. The species name is derived from the Greek word 'alphos', white, referring to the cell color [1]. Strain HI 11/12 ${ }^{\mathrm{T}}$ has been isolated from whitish streamers in Hveragerthi, Iceland [3]. Other strains of the species have been isolated from further high-temperature habitats in Iceland, but also in Kamchatka, Russia [1]. Members of the genus Thermocrinis appear to play a major ecological role in global biochemical cycles in such high-temperature habitats [4-7]. As currently defined the genus does not appear to form a 
monophyletic group, suggesting that further taxonomic work is necessary.

The large interest in the involvement of members of the family Aquificaceae in global biogeochemical cycles in high-temperature ecosystems made them attractive targets for early genome sequencing, e.g. 'Aquifex aeolicus' [8], the third hyperthermophile whose genome was already decoded in 1998 [9]. Like 'A. aeolicus' (a name that was never validly published) strain VF5 [10], Hydrogenobaculum sp. Y04AAS1 (CP001130, JGI unpublished) and Hydrogenivirga sp. 128-5-R1-1 (draft, Moore Foundation) do not represent type strains. Here we present a summary classification and a set of features for T. albus HI 11/12 ${ }^{\mathrm{T}}$, together with the description of the complete genomic sequencing and annotation.

\section{Classification and features}

Only four cultivated strains are reported for the species T. albus in addition to HI 11/12 ${ }^{\mathrm{T}}$ : Strains H7L1B and G3L1B from the same team that isolated $\mathrm{HI} 11 / 12^{\mathrm{T}}$ [1], and SRI-48 (AF255599) from hot spring microbial mats [11]. All three strains originate from Iceland and share 98.9-99.7\% 16S rRNA sequence identity with HI $11 / 12^{\mathrm{T}}$. The only non-Icelandic isolate, UZ23L3A (99.2\%), originates from Kamchatka (Russia) [1]. Almost all uncultured clones also originate from Iceland: clones KF6 and HV-7 (GU233821 and GU233840, >99\%) from water-saturated sediment in the Krafla and Hveragerdi geothermal systems, respectively. Clones GY1-1 and GY1-2 (GU233809, GU233812,
$>99 \%$ ) from water-saturated sediment Geysir hot springs; clone SUBT-1 (AF361217, 99.2\%) from subterranean hot springs [12], and clone PIce1 (AF301907, 99.3\%) as the dominant clone from a blue filament community of a thermal spring. Only clone PNG_TB_4A2.5H2_B11 (EF100635, 95.9\%) originated from a non-Icelandic source: a heated, arsenic-rich sediment of a shallow submarine hydrothermal system on Ambitle Island, Papua New Guinea. According to the original publication the $16 \mathrm{~S}$ rRNA of the type strain of the closest related species within the genus, T. ruber [3], shares 95.2\% sequence identity, whereas the type strains from the closest related genus, Hydrogenobacter, share 94.7-95.0\% sequence identity, as determined with EzTaxon [13]. However, as noted above the $16 \mathrm{~S}$ rDNA sequence of the $T$. ruber strain held in the DSMZ (DSM 12173) does not correspond with the sequence deposited (AJ005640). Environmental samples and metagenomic surveys featured in the NCBI database contain not a single sequence with $>88 \%$ sequence identity (as of February 2010), indicating that the species T. albus might play a rather limited and regional role in the environment.

Figure 1 shows the phylogenetic neighborhood of T. albus HI $11 / 12^{\mathrm{T}}$ in a $16 \mathrm{~S}$ rRNA based tree. The sequence of the single $16 \mathrm{~S}$ rRNA gene copy in the genome differs by seven nucleotides from the previously published 16S rRNA sequence generated from DSM 14484 (AJ278895), which contains two ambiguous base calls.

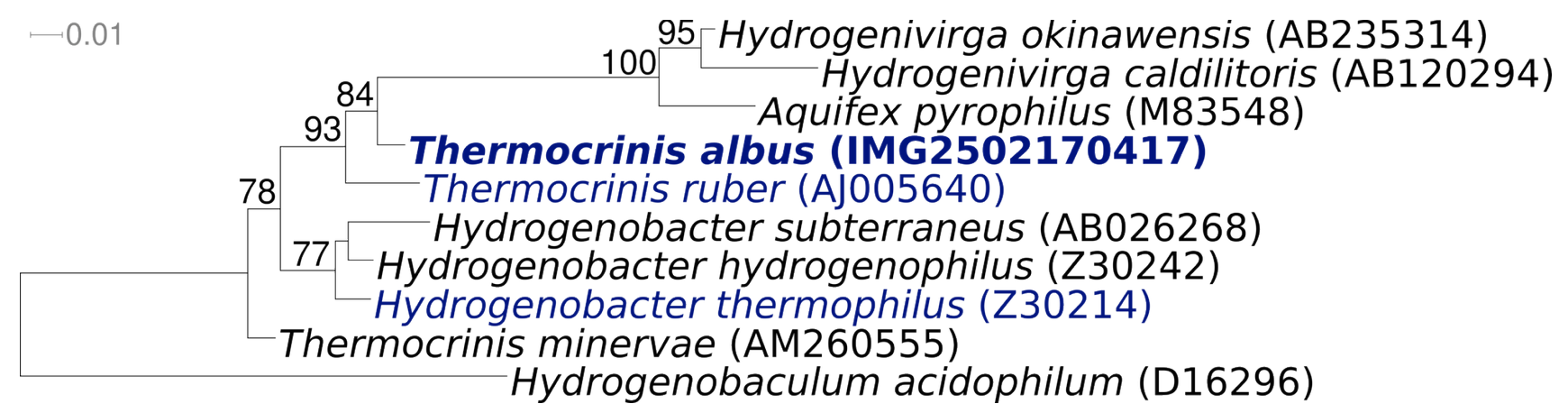

Figure 1. Phylogenetic tree highlighting the position of $T$. albus $\mathrm{HI} 11 / 12^{\top}$ relative to the other type strains within the family Aquificaceae. The tree was inferred from 1,439 aligned characters [14,15] of the 16S rRNA gene sequence under the maximum likelihood criterion [16] and rooted in accordance with the current taxonomy. The branches are scaled in terms of the expected number of substitutions per site. Numbers above branches are support values from 250 bootstrap replicates [17] if larger than 60\%. Lineages with type strain genome sequencing projects registered in GOLD [18] are shown in blue, published genomes in bold. Note that the sequence AJ005640 does not correspond with that from the type strain of T. ruber deposited as DSM 12173. 
When grown in the laboratory in a continuous flow of medium, for example in a glass chamber [1], strain HI $11 / 12^{\mathrm{T}}$ exhibits filamentous growth with a length of 10-60 $\mu \mathrm{m}$ [1]. When grown in static culture, the strain grows singly or in pairs [1]. The cells are short rods with $0.5-0.6 \mu \mathrm{m}$ in width by $1-3 \mu \mathrm{m}$ in length and motile by means of a monopolar monotrichous flagellum [1] (Figure 2 and Table 1). However, no flagella are visible in Figure 2. A regularly arrayed surface layer protein was not observed [1].
Strain $11 / 12^{\mathrm{T}}$ is microaerophilic with oxygen as electron acceptor [1]. Strain $11 / 12^{\mathrm{T}}$ appears to be strictly chemolithoautotrophic [1]. This differentiates T. albus from its two sister species T. ruber and T. minervae, which both can also grow chemoorganoheterotrophically [3,24]. Strain $11 / 12^{\mathrm{T}}$ grows optimally under microaerophilic conditions when hydrogen and sulfur are present simultaneously as electron donors [1], however, no growth is observed on nitrate. Physiological characteristics such as the wide temperature preference are reported in Table 1.

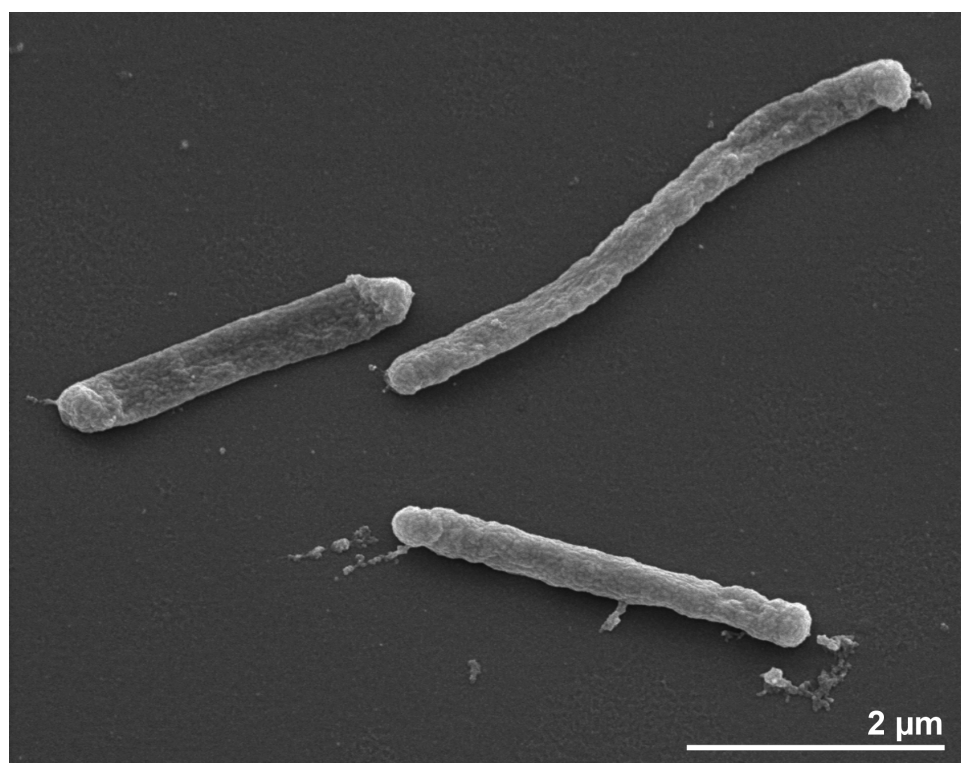

Figure 2. Scanning electron micrograph of T. albus $\mathrm{HI} 11 / 12^{\top}$

\section{Chemotaxonomy}

The cell wall of strain $11 / 12^{\mathrm{T}}$ contains mesodiaminopimelic acid [1]. There are no reports on the presence of a lipopolysaccharide in the typical Gram-negative cell wall, although there are reports of an LPS in Aquifex pyrophilus [27,28]. Cellular polyamines are important to stabilize cellular nucleic acid structure as a major function, and may function in thermophilic eubacteria as important chemotaxonomic markers [29]. In the genus Thermocrinis, the major polyamines are spermidine and a quaternary branched penta-amine, $\mathrm{N}^{4-}$ bis(aminopropyl)-norspermidine [29].

The major fatty acids in strain $\mathrm{HI} 11 / 12^{\mathrm{T}}$ are cyclo$\mathrm{C}_{21: 0}$ (42\%, 2 isomers), $\mathrm{C}_{18: 0}$ (14\%), $\mathrm{C}_{20: 1}$ cs11 (10.7\%), $\mathrm{C}_{20: 1 \mathrm{c} \Delta 13}(8.2 \%), \mathrm{C}_{20: 1} \mathrm{t} \Delta 11$ (5.4\%), and $\mathrm{C}_{20: 1}$ $\mathrm{t} \Delta 13(3.5 \%)$ [30]. All other fatty acids are below $2.9 \%$ ) [30]. The polar lipids are based on ester linked fatty acids (diacyl glycerols) and monoeth- er (probably in the form of monoester-monoether glycerols), in which the ether linked side chain includes $\mathrm{C}_{18: 0}(78.5 \%), \mathrm{C}_{20: 0}(2.0 \%), \mathrm{C}_{20: 1}(17.6 \%)$ and $\mathrm{C}_{21: 0}(1.9 \%)$ side chains [30].

T. albus belongs to a group of organisms where characteristic sulfur containing napthoquinones, menathioquinones (2-methylthio-1,4naphthoquinone) are present [31-35]. The polar lipids reported in members of the genera Aquifex, Hydrogenobaculum, Hydrogenothermus and Thermocrinis are also characteristic, with an unusual aminopentanetetrol phospholipid derivative being present in all strains examined $[36,37]$. Where detailed analyses have been carried out phosphatidylinositol has also been reported [37]. Stöhr et al. labeled these lipids PNL and PL1 respectively [31]. 
Table 1. Classification and general features of $T$. albus $\mathrm{HI} 11 / 12^{\top}$ according to the MIGS recommendations [19]

\begin{tabular}{|c|c|c|c|}
\hline MIGS ID & Property & Term & Evidence code \\
\hline & \multirow{8}{*}{ Current classification } & Domain Bacteria & TAS [20] \\
\hline & & Phylum Aquificae & TAS [21] \\
\hline & & Class Aquificae & TAS [21] \\
\hline & & Order Aquificales & TAS [22] \\
\hline & & Family Aquificaceae & TAS [23] \\
\hline & & Genus Thermocrinis & TAS [3] \\
\hline & & Species Thermocrinis albus & TAS [1] \\
\hline & & Type strain HI 11/12 & TAS [1] \\
\hline & Gram stain & Gram negative & TAS [1] \\
\hline & Cell shape & both filament and rod & TAS [1] \\
\hline & Motility & monopolar monotrichous flagellation & TAS [1] \\
\hline & Sporulation & non-sporulating & TAS [1] \\
\hline & Temperature range & $55-89^{\circ} \mathrm{C}$ & TAS [1] \\
\hline & Optimum temperature & not determined & TAS [1] \\
\hline & Salinity & $\leq 0.7 \%$ & TAS [1] \\
\hline \multirow[t]{3}{*}{ MIGS-22 } & Oxygen requirement & aerobic & TAS [1] \\
\hline & Carbon source & $\mathrm{CO}_{2}$, no organic carbon source reported & TAS $[1,24]$ \\
\hline & Energy source & chemolithoautotrophic & TAS [1] \\
\hline MIGS-6 & Habitat & hot spring & TAS [1] \\
\hline MIGS-15 & Biotic relationship & free living & TAS [1] \\
\hline \multirow[t]{3}{*}{ MIGS-14 } & Pathogenicity & not reported & TAS $[3,25]$ \\
\hline & Biosafety level & 1 & TAS [25] \\
\hline & Isolation & hot streamlet & TAS [1] \\
\hline MIGS-4 & Geographic location & Hverageroi, Iceland & TAS [1] \\
\hline MIGS-5 & Sample collection time & 1998 or before & TAS [3] \\
\hline $\begin{array}{l}\text { MIGS-4.1 } \\
\text { MIGS-4.2 }\end{array}$ & $\begin{array}{l}\text { Latitude } \\
\text { Longitude }\end{array}$ & $\begin{array}{l}64 \\
-21.2\end{array}$ & NAS \\
\hline MIGS-4.3 & Depth & unknown & \\
\hline MIGS-4.4 & Altitude & $30 \mathrm{~m}$ & NAS \\
\hline
\end{tabular}

Evidence codes - IDA: Inferred from Direct Assay (first time in publication); TAS: Traceable Author Statement (i.e., a direct report exists in the literature); NAS: Non-traceable Author Statement (i.e., not directly observed for the living, isolated sample, but based on a generally accepted property for the species, or anecdotal evidence). These evidence codes are from of the Gene Ontology project [26]. If the evidence code is IDA, then the property was directly observed for a live isolate by one of the authors or an expert mentioned in the acknowledgements.

\section{Genome sequencing and annotation Genome project history}

This organism was selected for sequencing on the basis of its phylogenetic position, and is part of the Genomic Encyclopedia of Bacteria and Archaea project [38]. The genome project is deposited in the Genome OnLine Database [18] and the com- plete genome sequence is deposited in GenBank. Sequencing, finishing and annotation were performed by the DOE Joint Genome Institute (JGI). A summary of the project information is shown in Table 2. 
Table 2. Genome sequencing project information

\begin{tabular}{lll}
\hline MIGS ID & Property & Term \\
\hline MIGS-31 & Finishing quality & Finished \\
MIGS-28 & Libraries used & Two 454 pyrosequence libraries, standard \\
MIGS-29 & Sequencing platforms & 454 Titanium, Illumina GAii \\
MIGS-31.2 & Sequencing coverage & 52.9× 454 Titanim; 298× Illumina \\
MIGS-30 & Assemblers & Newbler, Velvet, phrap \\
MIGS-32 & Gene calling method & Prodigal, GenePRIMP \\
& INSDC ID & CP001931 \\
& Genbank Date of Release & February 19, 2010 \\
& GOLD ID & Gc01206 \\
& NCBI project ID & 37275 \\
& Database: IMG-GEBA & 2502082116 \\
MIGS-13 & Source material identifier & DSM 14484 \\
& Project relevance & Tree of Life, GEBA \\
\hline
\end{tabular}

\section{Growth conditions and DNA isolation}

T. albus HI $11 / 12^{\mathrm{T}}$, DSM 14484, was grown in DSMZ medium 887 (OS Medium) [39] at $80^{\circ} \mathrm{C}$. DNA was isolated from 1-1.5 g of cell paste using MasterPure Gram-positive Kit (Epicentre MGP04100) with a modified protocol for cell lysis, using an additional $5 \mu \mathrm{l}$ mutanolysin to standard lysis solution, and one hour incubation on ice after the MPC-step.

\section{Genome sequencing and assembly}

The genome of strain HI $11 / 12^{\mathrm{T}}$ was sequenced using a combination of Illumina [40] and 454. An Illumina GAii shotgun library with reads of $447 \mathrm{Mb}$, a 454 Titanium draft library with average read length of 287 bases, and a paired end 454 library with average insert size of $17 \mathrm{~Kb}$ were generated for this genome. All general aspects of library construction and sequencing can be found at http://www.jgi.doe.gov/. Illumina sequencing data were assembled with VELVET [41], and the consensus sequences were shredded into $1.5 \mathrm{~kb}$ overlapped fake reads and assembled together with the 454 data. Draft assemblies were based on $79 \mathrm{Mb}$ 454 draft data. Newbler parameters were -consed a $50-1350-\mathrm{g}-\mathrm{m}-\mathrm{ml} 20$. The initial assembly contained six contigs in one scaffold. We converted the initial 454 assembly into a phrap assembly by making fake reads from the consensus, collecting the read pairs in the 454 paired end library. The Phred/Phrap/Consed software package was used for sequence assembly and quality assessment in the subsequent finishing process. After the shotgun stage, reads were assembled with parallel phrap. Possible mis-assemblies were corrected with gapResolution (unpublished), Dupfinisher or sequencing cloned bridging PCR fragments with sub- cloning or transposon bombing [42]. Gaps between contigs were closed by editing in Consed, by PCR and by Bubble PCR primer walks (J-F. Chan, unpublished). A total of 68 additional reactions were necessary to close gaps and to raise the quality of the finished sequence. The completed genome sequence had an error rate of less than 1 in 100,000 bp

\section{Genome annotation}

Genes were identified using Prodigal [43] as part of the Oak Ridge National Laboratory genome annotation pipeline, followed by a round of manual curation using the JGI GenePRIMP pipeline [44]. The predicted CDSs were translated and used to search the National Center for Biotechnology Information (NCBI) nonredundant database, UniProt, TIGRFam, Pfam, PRIAM, KEGG, COG, and InterPro databases. Additional gene prediction analysis and manual functional annotation was performed within the Integrated Microbial Genomes Expert Review (IMG-ER) platform [45].

\section{Genome properties}

The genome consists of a 1,500,577 bp long chromosome with a $46.9 \%$ GC content (Table 3 and Figure 3 ). Of the 1,650 genes predicted, 1,593 were protein coding genes, and 47 RNAs; 10 pseudogenes were identified. The majority of the proteincoding genes $(75.2 \%)$ were assigned with a putative function while those remaining were annotated as hypothetical proteins. The distribution of genes into COGs functional categories is presented in Table 4. 
Table 3. Genome Statistics

\begin{tabular}{lrr}
\hline Attribute & \multicolumn{1}{c}{ Value } & \% of Total \\
\hline Genome size (bp) & $1,500,577$ & $100.00 \%$ \\
DNA coding region (bp) & $1,459,457$ & $97.26 \%$ \\
DNA G+C content (bp) & 704,229 & $46.93 \%$ \\
Number of replicons & 1 & \\
Extrachromosomal elements & 0 & \\
Total genes & 1,650 & $100.00 \%$ \\
RNA genes & 47 & $2.85 \%$ \\
rRNA operons & 1 & \\
Protein-coding genes & 1,603 & $97.15 \%$ \\
Pseudo genes & 10 & $0.61 \%$ \\
Genes with function prediction & 1,241 & $75.21 \%$ \\
Genes in paralog clusters & 124 & $7.52 \%$ \\
Genes assigned to COGs & 1,316 & $79.76 \%$ \\
Genes assigned Pfam domains & 1,333 & $80.79 \%$ \\
Genes with signal peptides & 243 & $14.73 \%$ \\
Genes with transmembrane helices & 322 & $19.52 \%$ \\
CRISPR repeats & 4 & \\
\hline
\end{tabular}

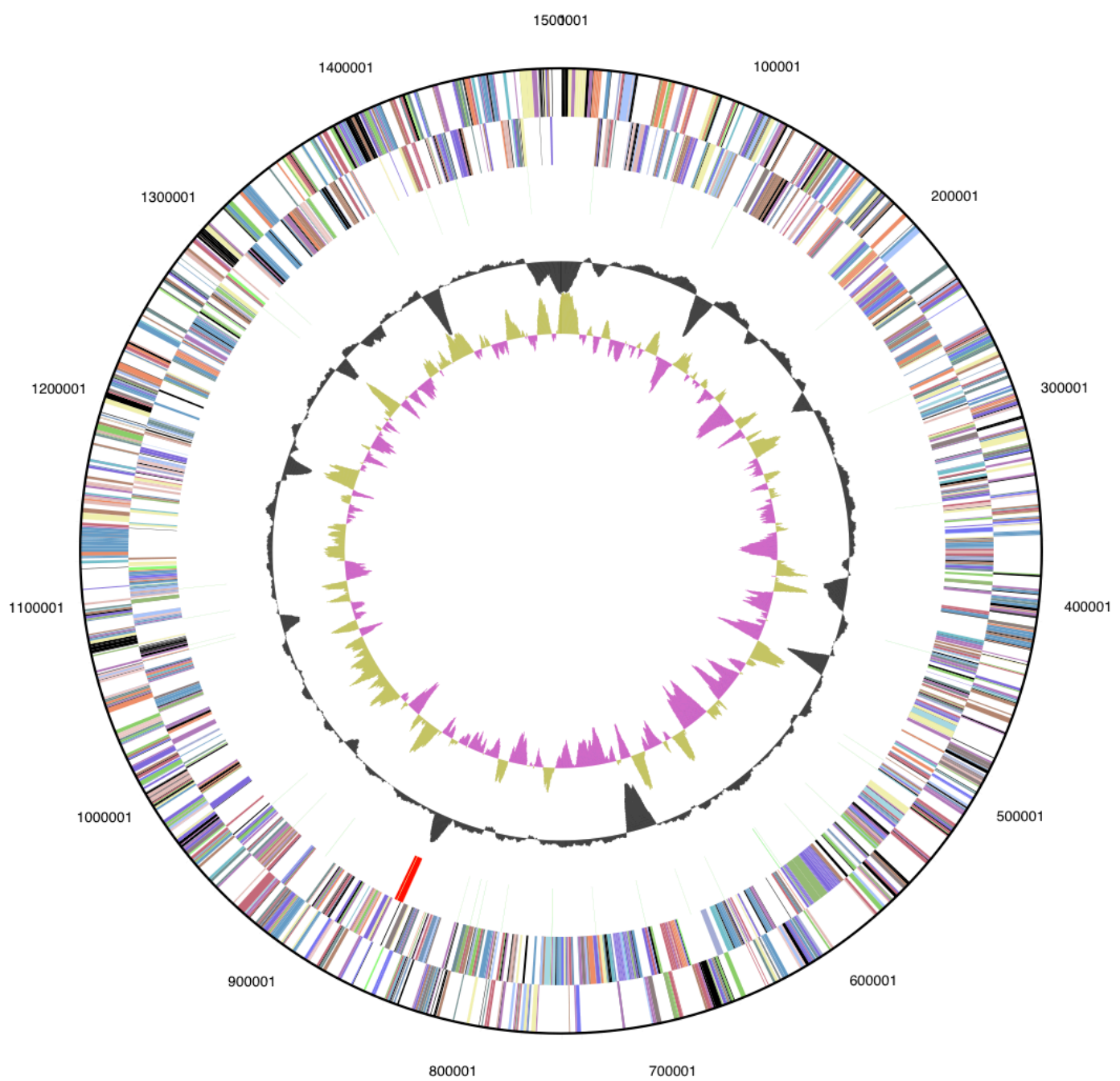

Figure 3. Graphical circular map of the genome. From outside to the center: Genes on forward strand (color by COG categories), Genes on reverse strand (color by COG categories), RNA genes (tRNAs green, rRNAs red, other RNAs black), GC content, GC skew. 
Table 4. Number of genes associated with the general COG functional categories

\begin{tabular}{crrl}
\hline Code & value & \%age & Description \\
\hline J & 131 & 8.2 & Translation, ribosomal structure and biogenesis \\
A & 0 & 0.0 & RNA processing and modification \\
K & 45 & 2.8 & Transcription \\
L & 80 & 5.0 & Replication, recombination and repair \\
B & 2 & 0.1 & Chromatin structure and dynamics \\
D & 0 & 0.0 & Cell cycle control, mitosis and meiosis \\
Y & 0 & 0.0 & Nuclear structure \\
V & 11 & 0.7 & Defense mechanisms \\
T & 47 & 2.9 & Signal transduction mechanisms \\
M & 111 & 6.9 & Cell wall/membrane biogenesis \\
N & 57 & 3.6 & Cell motility \\
Z & 0 & 0.0 & Cytoskeleton \\
W & 0 & 0.0 & Extracellular structures \\
U & 58 & 3.6 & Intracellular trafficking and secretion \\
O & 78 & 4.9 & Posttranslational modification, protein turnover, chaperones \\
C & 140 & 8.7 & Energy production and conversion \\
G & 48 & 3.0 & Carbohydrate transport and metabolism \\
E & 118 & 7.4 & Amino acid transport and metabolism \\
F & 49 & 3.1 & Nucleotide transport and metabolism \\
H & 96 & 6.0 & Coenzyme transport and metabolism \\
I & 39 & 2.4 & Lipid transport and metabolism \\
P & 74 & 4.6 & Inorganic ion transport and metabolism \\
Q & 16 & 1.0 & Secondary metabolites biosynthesis, transport and catabolism \\
R & 148 & 9.2 & General function prediction only \\
S & 79 & 4.9 & Function unknown \\
- & 334 & 20.8 & Not in COGs \\
\hline & & &
\end{tabular}

\section{Insights from the genome sequence}

With only very few papers published on the organism [1,2], and only one gene sequence (16S rRNA) available in GenBank from strain HI $11 / 12^{\mathrm{T}}$, a comparison of already known sequences to the here presented novel genomic data is rather meager for T. albus. As shown in Figure 1, there are presently no other type strain genomes from

\section{Acknowledgements}

This work was performed under the auspices of the US Department of Energy's Office of Science, Biological and Environmental Research Program, and by the University of California, Lawrence Berkeley National Laboratory under contract No. DE-AC02-05CH11231, Lawrence Livermore National Laboratory under Contract No. DE- the Aquificaceae available either to allow a meaningful comparative genomics analysis. This might change when other type/neotype strains of species within the genus Thermocrinis which are also part of the Genomic Encyclopedia of Bacteria and Archaea project [38] will become available in the near future.

AC52-07NA27344, Los Alamos National Laboratory under contract No. DE-AC02-06NA25396, and Oak Ridge National Laboratory under contract DE-AC05000R22725, as well as German Research Foundation (DFG) INST 599/1-1 and SI 1352/1-2. 


\section{References}

1. Eder W, Huber R. New isolates and physiological properties of the Aquificales and description of Thermocrinis albus sp. nov. Extremophiles 2002; 6:309-318. PubMed doi:10.1007/s00792-001$\underline{0259-y}$

2. Huber R, Eder W, Heldwein S, Wanner G, Huber $\mathrm{H}$, Rachel R, Stetter KO. Thermocrinis ruber gen. nov., sp. nov., a pink-filament-forming hyperthermophilic bacterium isolated from Yellowstone National Park. Appl Environ Microbiol 1998; 64:3576-3583. PubMed

3. Euzéby JP. List of bacterial names with standing in nomenclature: A folder available on the Internet. Int J Syst Bacteriol 1997; 47:590-592. PubMed doi:10.1099/00207713-47-2-590

4. Hall JR, Mitchell KR, Jackson-Weaver O, Kooser AS, Cron BR, Crossey LJ, Takacs-Vesbach CD. Molecular characterization of the diversity and distribution of a thermal spring microbial community by using rRNA and metabolic genes. Appl Environ Microbiol 2008; 74:4910-4922. PubMed doi:10.1128/AEM.00233-08

5. Connon SA, Koski AK, Neal AL, Wood SA, Magnuson TS. Ecophysiology and geochemistry of microbial arsenic oxidation within a high arsenic, circumneutral hot spring system of the Alvord Desert. FEMS Microbiol Ecol 2008; 64:117-128. PubMed doi:10.1111/j.1574-6941.2008.00456.x

6. Hamamura N, Macur RE, Korf S, Ackerman G, Taylor WP, Kozubal M, Reysenbach AL, Inskeep WP. Linking microbial oxidation of arsenic with detection and phylogenetic analysis of arsenite oxidase genes in diverse geothermal environments. Environ Microbiol 2009; 11:421-431. PubMed doi:10.1111/j.1462-2920.2008.01781.x

7. Hügler $M$, Huber $H$, Molyneaux SJ, Vetriani $C$, Sievert SM. Autotrophic $\mathrm{CO}_{2}$ fixation via the reductive tricarboxylic acid cycle in different lineages within the phylum Aquificae: evidence for two ways of citrate cleavage. Environ Microbiol 2007; 9:81-92. PubMed doi:10.1111/j.14622920.2006.01118.x

8. Deckert G, Warren PV, Gaasterland T, Young WG, Lennox AL, Graham DE, Overbeek R, Snead MA, Keller M, Aujay M, et al. The complete genome of the hyperthermophilic bacterium Aquifex aeolicus. Nature 1998; 392:353-358. PubMed doi:10.1038/32831
9. Klenk HP. The genomics of a hot-water maker. Nat Genet 1998; 19:4-6. PubMed doi:10.1038/ng0598-4

10. Huber R, Stetter KO. Genus I. Aquifex Huber and Stetter 1992e, 656 ${ }^{\mathrm{VP}}$ (Effective publication: Huber and Stetter in Huber, Wilharm, Huber, Trincone, Burggraf, König, Rachel, Rockinger, Fricke and Stetter 1992b, 349). In: Boone DR, Castenholz WR, Garrity GM (eds), Bergey's Manual of Systematic Bacteriology, second edition, vol. 1 (The Archaea and the deeply branching and phototrophic Bacteria), Springer, New York, 2001, pp. 360-362.

11. Skirnisdottir S, Hreggvidsson GO, Hjorleifsdottir S, Marteinsson VT, Petursdottir SK, Holst O, Kristjansson JK. Influence of sulfide and temperature on species composition and community structure of hot spring microbial mats. Appl Environ Microbiol 2000; 66:2835-2841. PubMed doi:10.1128/AEM.66.7.2835-2841.2000

12. Marteinsson VT, Hauksdottir $\mathrm{S}$, Hobel CF, Kristmannsdottir $\mathrm{H}$, Hreggvidsson GO, Kristjansson JK. Phylogenetic diversity analysis of subterranean hot springs in Iceland. App/ Environ Microbiol 2001; 67:4242-4248. PubMed doi:10.1128/AEM.67.9.4242-4248.2001

13. Chun J, Lee JH, Jung $Y$, Kim $M$, Kim S, Kim BK, Lim YW. EzTaxon: a web-based tool for the identification of prokaryotes based on $16 \mathrm{~S}$ ribosomal RNA gene sequences. Int I Syst Evol Microbiol 2007; 57:2259-2261. PubMed doi:10.1099/ijs.0.64915-0

14. Castresana J. Selection of conserved blocks from multiple alignments for their use in phylogenetic analysis. Mol Biol Evol 2000; 17:540-552. PubMed

15. Lee C, Grasso C, Sharlow MF. Multiple sequence alignment using partial order graphs. Bioinformatics 2002; 18:452-464. PubMed doi:10.1093/bioinformatics/18.3.452

16. Stamatakis A, Hoover P, Rougemont J. A rapid bootstrap algorithm for the RAxML web servers. Syst Biol 2008; 57:758-771. PubMed doi:10.1080/10635150802429642

17. Pattengale ND, Alipour M, Bininda-Emonds ORP, Moret BME, Stamatakis A. How many bootstrap replicates are necessary? Lect Notes Comput Sci 2009; 5541:184-200. doi:10.1007/978-3-64202008-7_13 
18. Liolios K, Chen IM, Mavromatis K, Tavernarakis N, Hugenholtz P, Markowitz VM, Kyrpides NC. The Genomes On Line Database (GOLD) in 2009: status of genomic and metagenomic projects and their associated metadata. Nucleic Acids Res 2010; 38:D346-D354. PubMed doi:10.1093/nar/gkp848

19. Field D, Garrity G, Gray T, Morrison N, Selengut J, Sterk P, Tatusova T, Thomson N, Allen MJ, Angiuoli $S V$, et al. The minimum information about a genome sequence (MIGS) specification. Nat Biotechnol 2008; 26:541-547. PubMed doi:10.1038/nbt1360

20. Woese CR, Kandler O, Wheelis ML. Towards a natural system of organisms: proposal for the domains Archaea, Bacteria, and Eucarya. Proc Natl Acad Sci USA 1990; 87:4576-4579. PubMed doi:10.1073/pnas.87.12.4576

21. Reysenbach AL. Class I, Aquificae phyl. nov. In: Garrity GM, Boone DR, Castenholz RW (eds), Bergey's Manual of Systematic Bacteriology, Second Edition, Vol. 1, Springer, NY, 2001, p. 359.

22. Reysenbach AL. Order I, Aquificae class nov. In: Garrity GM, Boone DR, Castenholz RW (eds), Bergey's Manual of Systematic Bacteriology, Second Edition, Vol. 1, Springer, NY, 2001, p. 359.

23. Reysenbach AL. Family I, Aquificaceae fam. nov. In: Garrity GM, Boone DR, Castenholz RW (eds), Bergey's Manual of Systematic Bacteriology, Second Edition, Vol. 1, Springer, NY, 2001, p. 360 .

24. Caldwell SL, Liu Y, Ferrera I, Beveridge T, Reysenbach A-L. Thermocrinis minervae sp. nov., a hydrogen- and sulfur-oxidizing, thermophilic member of the Aquificales from a Costa Rican terrestrial hot spring. Int I Syst Evol Microbiol (In press). $\underline{\text { PubMed }}$

25. Classification of Bacteria and Archaea in risk groups Technical rules for biological agents www.baua.de TRBA 466.

26. Ashburner M, Ball CA, Blake JA, Botstein D, Butler H, Cherry JM, Davis AP, Dolinski K, Dwight SS, Eppig JT, et al. Gene Ontology: tool for the unification of biology. Nat Genet 2000; 25:25-29. PubMed doi:10.1038/75556

27. Plötz BM, Lindner B, Stetter KO, Holst OJ. Characterization of a novel lipid A containing Dgalacturonic acid that replaces phosphate residues. The structure of the lipid A of the lipopolysaccharide from the hyperthermophilic bacterium
Aquifex pyrophilus. Biol Chem 2000; 275:1122211228. doi:10.1074/jbc.275.15.11222

28. Mamat U, Schmidt HE, Lindner B, Fukase K, Hanuszkiewicz A, Wu J, Meredith TC, Woodard RW, Hilgenfeld R, Mesters JR, et al. WaaA of the hyperthermophilic bacterium Aquifex aeolicus is a monofunctional 3-deoxy-d-manno-oct-2-ulosonic acid transferase involved in lipopolysaccharide biosynthesis. J Biol Chem 2009; 284:2224822262. PubMed doi:10.1074/jbc.M109.033308

29. Hosoya R, Hamana K, Niitsu M, Itoh T. Polyamine analysis for chemotaxonomy of thermophilic eubacteria: Polyamine distribution profiles within the orders Aquificales, Thermotogales, Thermodesulfobacteriales, Thermales, Thermoanaerobacteriales, Clostridiales and Bacillales. I Gen Appl Microbiol 2004; 50:271-287. PubMed doi:10.2323/jgam.50.271

30. Jahnke LL, Eder W, Huber R, Hope JM, Hinrichs KU, Hayes JM, Des Marais DJ, Cady SL, Summons RE. Signature lipids and stable carbon isotope analyses of Octopus Spring hyperthermophilic communities compared with those of aquificales representatives. Appl Environ Microbiol 2001; 67:5179-5189. PubMed doi:10.1128/AEM.67.11.5179-5189.2001

31. Stöhr R, Waberski A, Völker H, Tindall BJ, Thomm M. Hydrogenothermus marinus gen. nov., sp. nov., a novel thermophilic hydrogenoxidizing bacterium, recognition of Calderobacterium hydrogenophilum as a member of the genus Hydrogenobacter and proposal of the reclassification of Hydrogenobacter acidophilus as Hydrogenobaculum acidophilum gen. nov., comb. nov., in the phylum 'Hydrogenobacter/Aquifex'. Int J Syst Evol Microbiol 2001; 51:1853-1862. PubMed

32. Ishii M, Kawasumi T, Igarashi Y, Kodama T, Minoda $Y$. 2-Methylthio-1,4-naphthoquinone, a new quinone from an extremely thermophilic hydrogen bacterium. Agric Biol Chem 1983; 47:167169.

33. Ishii M, Kawasumi T, Igarashi $Y$, Kodama T, Minoda Y. 2-Methylthio-1,4-naphthoquinone, a unique sulfur containing quinone from a thermophilic hydrogen-oxidizing bacterium, Hydrogenobacter thermophilus. J Bacteriol 1987;

169:2380-2384. PubMed

34. Nishihara $\mathrm{H}$, Igarashi $\mathrm{Y}$, Kodama T. A new isolate of Hydrogenobacter, an obligately chemolithoautotrophic, thermophilic, halophilic and aerobic hydrogen-oxidizing bacterium from seaside saline hot spring. Arch Microbiol 1990; 153:294-298. doi:10.1007/BF00249085 
Wirth et al.

35. Shima S, Suzuki KI. Hydrogenobacter acidophilus sp. nov., a thermoacidophilic, aerobic, hydrogenoxidizing bacterium requiring elemental sulfur for growth. Int / Syst Bacteriol 1993; 43:703-708. doi:10.1099/00207713-43-4-703

36. Sturt HF, Summons RE, Smith K, Elvert M. Hinrichs K-U. Intact polar membrane lipids in prokaryotes and sediments deciphered by highperformance liquid chromatography/electrospray ionization multistage mass spectrometry - new biomarkers for biogeochemistry and microbial ecology. Rapid Commun Mass Spectrom 2004; 18:617-628. PubMed doi:10.1002/rcm.1378

37. Yoshino J, Sugiyama Y, Sakuda S, Kodama T, Nagasawa $H$, Ishii $M$, Igarashi $Y$. Chemical structure of a novel aminophospholipid from Hydrogenobacter thermophilus strain TK-6. J Bacteriol 2001; 183:6302-6304. PubMed doi:10.1128//B.183.21.6302-6304.2001

38. Wu D, Hugenholtz P, Mavromatis K, Pukall R, Dalin E, Ivanova NN, Kunin V, Goodwin L, Wu $M$, Tindall BJ, et al. A phylogeny-driven genomic encyclopaedia of Bacteria and Archaea. Nature 2009; 462:1056-1060. PubMed doi:10.1038/nature08656

39. List of growth media used at DSMZ: http://www.dsmz.de/microorganisms/media list.p $\underline{\mathrm{hp}}$
40. Bennett S. Solexa Ltd. Pharmacogenomics 2004; 5:433-438. PubMed doi:10.1517/14622416.5.4.433

41. Zerbino DR, Birney E. Velvet: algorithms for de novo short read assembly using de Bruijn graphs. Genome Res 2008; 18:821-829. PubMed doi:10.1101/gr.074492.107

42. Sims D, Brettin T, Detter J, Han C, Lapidus A, Copeland A, Glavina Del Rio T, Nolan M, Chen F, Lucas S, et al. Complete genome sequence of $K y$ tococcus sedentarius type strain $\left(541^{\mathrm{T}}\right)$. Stand Genomic Sci 2009; 1:12-20. doi:10.4056/sigs.761

43. Hyatt D, Chen GL, Locascio PF, Land ML, Larimer FW, Hauser LJ. Prodigal Prokaryotic Dynamic Programming Genefinding Algorithm. BMC Bioinformatics 2010; 11:119. PubMed doi:10.1186/1471-2105-11-119

44. Pati A, Ivanova N, Mikhailova N, Ovchinikova G, Hooper SD, Lykidis A, Kyrpides NC. GenePRIMP: A Gene Prediction Improvement Pipeline for microbial genomes. Nat Methods (In press).

45. Markowitz VM, Ivanova NN, Chen IMA, Chu K, Kyrpides NC. IMG ER: a system for microbial genome annotation expert review and curation. Bioinformatics 2009; 25:2271-2278. PubMed doi:10.1093/bioinformatics/btp393 